(C) Elsevier/INRA

Original article

\title{
Genetic variability of muscle biological characteristics of young Limousin bulls
}

\author{
G Renand ${ }^{1}$, C Jurie ${ }^{2}$, J Robelin ${ }^{2}$, B Picard ${ }^{2}$, \\ $\mathrm{Y} \mathrm{Geay}^{2}$, F Ménissier ${ }^{1}$ \\ ${ }^{1}$ Institut national de la recherche agronomique, station de génétique \\ quantitative et appliquée, 78352 Jouy-en-Josas cedex, France; \\ ${ }^{2}$ Institut national de la recherche agronomique, laboratoire croissance et métabolisme des \\ herbivores, UR croissance musculaire, 63122 Saint-Genès-Champanelle, France
}

(Received 6 May 1994; accepted 13 January 1995)

Summary - Genetic parameters of 4 muscle biological characteristics (protein to DNA ratio (Pro/DNA), lactate dehydrogenase (LDH) activity, isocitrate dehydrogenase (ICDH) activity and the proportion of type I myosin heavy chains (MHC I)), in the Semitendinosus and the Longissimus thoracis, were estimated simultaneously with average daily gain (ADG), 480-d final weight (FW), carcass lean and fat contents (CL\% and CF\% respectively) in a sample of young Limousin bulls tested in station. The data came from 144 animals, the progeny of 15 sires. Sire and residual variances and covariances were estimated using an expectation maximization restricted maximum likelihood (EM-REML) procedure applied to a multitrait mixed model. Heritability coefficients of production traits, ADG, FW, CL\% and CF\%, were $0.19,0.49,0.39$ and 0.43 , respectively, while heritability coefficients of muscle characteristics, Pro/DNA, LDH, ICDH and MHC I, were $0.11,0.26,1.03$ and 0.35 respectively, in the Semitendinosus muscle and $0.29,0.31,0.28$ and 0.41 , respectively, in the Longissimus thoracis muscle. In both muscles, the oxidative activity of the ICDH appeared to be genetically associated with the proportion of type I myosin heavy chains and opposed to the glycolytic activity of the LDH. The LDH activity was clearly associated with higher muscle-to-fat ratio, while the opposite relationship was observed between that ratio and the ICDH activity or the MHC I proportion.

beef cattle / genetic parameter / growth / carcass / muscle characteristics

Résumé - Variabilité génétique de caractéristiques biologiques du muscle chez des taurillons Limousins. Les paramètres génétiques de 4 caractéristiques biologiques - le rapport protéines /ADN (Pro/DNA), les activités de la lactate déshydrogénase (LDH) et de l'isocitrate déshydrogénase (ICDH) et la proportion en chaînes lourdes de myosine lente (MHC I) - des muscles Semitendinosus et Longissimus thoracis, et ceux du gain moyen quotidien $(A D G)$, du poids vif final à $480 j(F W)$ et des teneurs de la carcasse en muscles et en dépôts adipeux (CL\% and CF\% respectivement), ont été estimés simultanément à partir d'un échantillon de taurillons Limousins contrôlés en station. Le fichier comprenait 144 veaux issus de 15 pères testés sur descendance. Les variances et covariances paternelles 
et résiduelles ont été estimées par la méthode du maximum de vraisemblance restreinte, avec l'algorithme d'espérance-maximisation, appliquée à un modèle mixte multicaractère (EM-REML). Les coefficients d'héritabilité des variables de production, ADG, FW, CL\% et $C F \%$, s'élevaient respectivement à 0,19, 0,49, 0,39 et 0,43, tandis que les coefficients d'héritabilité des caractéristiques musculaires, Pro/DNA, LDH, ICDH et MHC I, valaient respectivement 0,11, 0,26, 1,03 et 0,35 dans le muscle Semitendinosus et 0,29, 0,31, 0,28 et 0,41 dans le muscle Longissimus thoracis. Dans les 2 muscles, l'activité oxidative de l'ICDH était génétiquement associée à la proportion de myosine lente et opposée à l'activité glycolytique du LDH. Cette activité du LDH était positivement corrélée avec le rapport muscles / dépôts adipeux, alors qu'une relation inverse était observée avec l'activité de l'ICDH et la proportion de MHC I.

bovin à viande / paramètre génétique / croissance / carcasse / caractéristique musculaire

\section{INTRODUCTION}

The objective for improving beef traits in most production systems is to simultaneously increase the economic margin of producers and meet the consumers' requirements relative to meat quality. Among the numerous components involved in the biological efficiency of meat production, muscle growth capacity appears to be determinant whatever the species (Dickerson, 1982; Sellier et al, 1992). In cattle, a large genetic variability of beef traits has been shown to exist among breeds as well as within breeds (Koch et al, 1982; Cundiff et al, 1986; Renand et al, 1992). Genetic improvement can therefore be obtained by the appropriate choice of breeding animals, since heritability coefficients average $0.35-0.40$ for live growth traits and $0.45-0.50$ for carcass composition traits.

In most selection programs the primary selection criterion is live growth rate. Up to now, meat quality has not been included in beef selection programs since there is no economic incentive for improving it and objective methods of measurement on a large scale are still lacking. However different studies have shown that a moderate but significant proportion of the large individual variability observed for meat quality traits is under genetic control among or within breeds (Koch et al, 1982; Cundiff et al, 1986; Renand, 1993). These results suggest that genetic improvement could be made as long as potential sires could be tested and selected, although the estimated heritability coefficients are lower than for production traits, $0.20-0.30$ on average (Renand, 1993).

Although not directly selected, meat quality components may change as a consequence of selection for production traits, as long as they are genetically linked. Therefore definition of selection programs to improve meat production efficiency and meat quality requires the genetic variability of the different components to be estimated simultaneously.

The quality of the meat to be taken into account are the sensory measurements related to the color, tenderness, flavor and juiciness of the higher priced joints that are roasted or broiled. Most of these quality traits, especially tenderness, originate from post-mortem aging of muscles and are therefore related to the biological 
characteristics of the muscles before slaughter, and more precisely to the contractile and metabolic types of muscles (Valin, 1988; Ouali, 1991). Three types of fibers can be distinguished in adult cattle according to their contractile activity (slow or fast) and their energy metabolism (aerobic or anaerobic): type I or slow oxidative (SO), type IIa or fast oxidative-glycolytic (FOG), and type IIb or fast glycolytic (FG). However very little is known about the genetic variability of these characteristics and their relationship with production traits. The present contribution aims at giving the first within-breed genetic parameters of muscle biological characteristics of French Limousin cattle.

\section{MATERIALS AND METHODS}

\section{Animals}

For estimating the genetic variability in the French Limousin breed, the progeny testing results of sires used by artifical insemination (AI) were used. The selection program of Limousin AI sires includes a centralized progeny testing. Each year, purebred Limousin cows are randomly inseminated with the semen of potential young sires and a sample of about 30 male progeny per sire is gathered in a central testing station after weaning at 7-8 months of age. The young bull progeny are distributed in contemporary groups according to their birth date and fed a similar diet with corn silage adequately complemented and distributed ad libitum, up to a constant final slaughter age of 16 months. During fattening, cattle are weighed monthly. They are tested on live growth traits and on carcass weight and conformation.

In 1991, a group of 15 potential AI sires was tested on 432 young bull progeny slaughtered between 9 April and 23 July. A sub-sample of these progeny was selected among the young bulls slaughtered between 28 May and 2 July to study the carcass composition and muscle characteristics. It included 144 animals after 3 of them had been eliminated due to sanitary problems. The constitution of these samples is reported in table $\mathrm{I}$. In the experimental sub-sample each sire was represented by 8-10 progeny (9.6 on average). The testing inseminations were performed in different districts of south-western France with different management and climate conditions, and so 3 different groups of origin (region $\times$ management) were defined, with 37-68 animals each. The 144 experimental animals were born in a 2 month period and were distributed in 6 different contemporary groups, with 20-28 animals each.

\section{Traits analysed}

Average daily gain (ADG) during the 8 months fattening period and 480 -d live weight $(\mathrm{FW})$ before leaving for slaughtering were recorded. Carcass composition was estimated according to Robelin and Geay (1975) from the dissection of the 11th rib cut. Carcass lean or fat contents were computed as the ratio of the estimated lean or fat weights to the cold carcass weight.

According to most studies on meat quality, muscle characteristics were measured on a sample of the Semitendinosus (ST) and Longissimus thoracis (LT) muscles 
Table I. Compared overall means and overall standard deviations in the whole progeny testing and the experimental sample.

\begin{tabular}{lrrrr}
\hline \multirow{2}{*}{ Traits } & \multicolumn{2}{c}{ Progeny testing $(\mathrm{n}=432)$} & \multicolumn{3}{c}{ Experimental sample $(\mathrm{n}=144)$} \\
& Mean & \multicolumn{1}{c}{$s d^{\mathrm{a}}$} & Mean & \multicolumn{1}{c}{$s d^{\mathrm{a}}$} \\
\hline Average daily gain $(\mathrm{g} / \mathrm{d})$ & 1325 & 154 & 1324 & 173 \\
Final age (d) & 479 & 7 & 480 & 3 \\
Final weight $(\mathrm{kg})$ & 596 & 51 & 594 & 52 \\
Carcass weight $(\mathrm{kg})$ & 367 & 33 & 367 & 34 \\
\hline
\end{tabular}

${ }^{\mathrm{a}} \mathrm{sd}=$ standard deviation.

since they correspond to higher priced joints where sensory qualities are important. Measurement methods have been fully described by Jurie et al, 1994. The protein and DNA contents were measured (Lowry et al, 1951; Labarca and Paigen, 1980) and combined into a ratio of protein to DNA (Pro/DNA) as an indirect measure of protein synthesis and hypertrophy. The oxidative metabolism has been quantified by the measurement of the isocitrate dehydrogenase (ICDH) activity (Briand et al, 1981). The anaerobic glycolytic metabolism has been quantified by the measurement of the lactate dehydrogenase (LDH) activity (Ansay, 1974). The contractile type has been quantified by the proportion of type I (slow twitch) myosin heavy chains (MHC I) measured by Elisa immunological assay (Picard et al, 1994).

\section{Analysis methods}

In addition to the sire effect $\left(s_{k}\right)$, the factor of interest to estimate the genetic variability, the statistical model included both the origin $\left(O_{i}\right)$ and the contemporary group $\left(C_{j}\right)$ effects for correction. For each trait, the model was as follows:

$$
y_{i j k l}=O_{i}+C_{j}+s_{k}+e_{i j k l}
$$

where $y_{i j k l}$ was the record of a trait for a young bull from the $i$ th group of origin, in the $j$ th contemporary group and progeny of the $k$ th sire; $O_{i}$ was the fixed effect of the $i$ th group of origin; $C_{j}$ was the fixed effect of the $j$ th contemporary group; $s_{k}$ was the random effect of the $k$ th sire, sires being unrelated; $e_{i j k l}$ was the random residual.

All traits were analysed simultaneously in a multiple-trait model. The sire and residual variances and covariances were estimated by the restricted maximum likelihood (REML) method (Patterson and Thompson, 1971), using the expectation maximization (EM) algorithm (Dempster et al, 1977). Taking advantage of the fact that all traits had identical design matrices, a canonical transformation was used. The estimated (co)variances were classically combined to compute heritability, genetic and phenotypic correlation coefficients. No exact standard errors of the genetic parameters could be computed due to the method used to estimate the (co)variances. Roughly, only heritability coefficients higher than 0.4 could be considered significant. A principal component analysis has been performed on the genetic correlation matrix for each muscle including both production traits and biological characteristics. 


\section{RESULTS AND DISCUSSION}

\section{Fixed effects, means and phenotypic standard deviations}

Among the fixed effects included in the model, the contemporary group effect was significant on almost all the traits, certainly resulting from numerous unidentified environmental effects. The origin group effects appeared to be significant only for live growth traits. When tested in the station, the calves that were reared indoors in their herd of origin had a lower growth rate $(-8 \%)$ as compared to calves reared at pasture. They also had a lower carcass fat content $(-0.5$ percent units) and a lower protein to DNA ratio $(-5 \%)$ in both muscles. However these effects were not significant.

Means, phenotypic standard deviations and heritability coefficients are reported in table II. As previously described in detail by Jurie et al (1994) the energy metabolism was more glycolytic and less oxidative, and the contractile type was faster in the ST as compared to the LT muscle. The phenotypic variability of the biological characteristics measured in both muscles was relatively large, with coefficients of variation around $20 \%$. This variability was larger than those observed for production traits, which showed coefficients of variation lower than $13 \%$.

Table II. Means, phenotypic standard deviations and heritability coefficients.

\begin{tabular}{|c|c|c|c|}
\hline & Overall mean & Phenotypic sd $d^{\mathrm{a}}$ & Heritability coefficient ${ }^{\mathrm{b}}$ \\
\hline \multicolumn{4}{|l|}{ Production traits } \\
\hline Average daily gain $(\mathrm{g} / \mathrm{d})$ & 1324 & 168 & $0.19 \pm 0.23$ \\
\hline Final weight $(\mathrm{kg})$ & 594 & 50 & $0.49 \pm 0.30$ \\
\hline \multicolumn{4}{|l|}{ Carcass composition traits } \\
\hline Lean content (\%) & 75.6 & 1.3 & $0.39 \pm 0.28$ \\
\hline Fat content (\%) & 11.1 & 1.4 & $0.43 \pm 0.29$ \\
\hline \multicolumn{4}{|l|}{$S T$ characteristics } \\
\hline Protein/DNA (mg/mg) & 434 & 72 & $0.11 \pm 0.21$ \\
\hline $\mathrm{LDH}^{\mathrm{c}}$ (nkat/g) & 136 & 16 & $0.26 \pm 0.25$ \\
\hline $\mathrm{ICDH}^{\mathrm{d}}$ (pkat/g) & 152 & 36 & $1.03 \pm 0.42$ \\
\hline $\mathrm{MHC} \mathrm{I}^{\mathrm{e}}(\%)$ & 22.7 & 6.6 & $0.35 \pm 0.27$ \\
\hline \multicolumn{4}{|l|}{ LT characteristics } \\
\hline Protein/DNA (mg/mg) & 387 & 62 & $0.29 \pm 0.26$ \\
\hline $\mathrm{LDH}^{\mathrm{c}}$ (nkat/g) & 123 & 25 & $0.31 \pm 0.26$ \\
\hline $\mathrm{ICDH}^{\mathrm{d}}($ pkat/g) & 175 & 42 & $0.28 \pm 0.25$ \\
\hline $\operatorname{MHC~} \mathrm{I}^{\mathrm{e}}(\%)$ & 27.2 & 7.1 & $0.41 \pm 0.28$ \\
\hline
\end{tabular}

${ }^{a}$ sd $=$ standard deviation; ${ }^{b}$ heritability coefficients \pm approximate standard error; ${ }^{\mathrm{c}} \mathrm{LDH}=$ lactate dehydrogenase activity; ${ }^{\mathrm{d}} \mathrm{ICDH}=$ isocitrate dehydrogenase activity;

${ }^{\mathrm{e}} \mathrm{MHC} \mathrm{I}=$ proportion of type I myosin heavy chains. 
Heritability coefficients of live growth traits were within the range of most of the estimates published in the literature: in the lower range for ADG $\left(h^{2}=0.19\right)$ and in the upper range for final age weight $\left(h^{2}=0.49\right)$. The heritability of carcass composition traits, $h^{2}=0.38$ for lean and $h^{2}=0.43$ for fat content, were close to the average values computed from estimates in the literature, $h^{2}=0.44$ and $h^{2}=0.49$, respectively (Renand et al, 1992). These estimates showed that the genetic variability in this sample of Limousin young bulls was representative of the genetic variability generally observed for similar traits measured on cattle tested in stations.

Most of the biological muscle characteristics (6 out of 8 ) presented heritability coefficients in the range $h^{2}=0.26$ to 0.41 . However, 2 characteristics measured on the ST muscle had quite different values, as low as $h^{2}=0.11$ for the ratio protein/DNA and, surprisingly, as high as 1.03 for ICDH. There may be many reasons for these extreme values and the relatively limited size of the sample was certainly the major one. Except for these 2 characteristics, the apparent genetic variability of the biological muscle characteristics was equivalent to the genetic variability of live growth traits and therefore slightly inferior to the genetic variability of carcass composition traits; about $30 \%$ of the observed variability of these characteristics appeared to be under control of additive genetic effects. In the literature no similar characteristics could be found for comparison. Andersen et al (1977) published estimates of heritability coefficients of fiber type percentages in the Longissimus dorsi of Danish Red, or Danish Black and White, or Danish Red and White cattle. The fibers were typed on histological slices stained with Sudan black B, which is particularly absorbed by the lipids predominantly associated with red fibers and to a less extent with intermediary fibers. The heritability coefficients they obtained averaged $h^{2}=0.29\left(h^{2}=0.22\right.$ to $\left.=0.38\right)$ for fiber type percentages and diameters. These estimates were slightly lower than the coefficients estimated for live growth or carcass composition traits they found in their study (respectively around $h^{2}=0.42$ and $=0.48$ ). In sheep, Vigneron et al $(1986)$ found that the percentage of type b (type I) fibers in the Scutuloauricularis superficialis accessorius muscle, a small muscle of the ear, determined histoenzymologically, had a relatively large genetic component, $h^{2}=0.27,0.46$, and 0.97 in 3 different breeds (Mérinos d'Arles, Berrichon $\times$ Romanov, and Île de France, respectively). In swine, no estimate of within-breed genetic variability could be found for fiber types, while estimates of fiber diameter averaged $h^{2}=0.32$ in 2 Danish studies reported by Staun (1972).

\section{Phenotypic correlations}

The phenotypic correlation coefficients $\left(r_{p}\right)$ are reported in table III. They were not markedly different from the raw correlations previously computed from variables uncorrected for the identified fixed effects (Jurie et al, 1994). In general these coefficients were low. The only notable relationships were the positive relationship between the oxidative activity $(\mathrm{ICDH})$ and the proportion of type I myosin $\left(r_{p}=\right.$ +0.31 and $r_{p}=+0.41$ respectively in the ST and the LT muscle) both in opposition to the glycolytic activity $\left(r_{p}=-0.20\right.$ and $r_{p}=-0.30$ respectively for the oxidative activity and $r_{p}=-0.44$ and $r_{p}=-0.48$ respectively for the proportion of type I 
myosin). The phenotypic correlations between similar characteristics measured in both muscles were very low. Similarly no clear phenotypic relationship appeared between muscle biological characteristics and production traits.

Table III. Phenotypic correlation coefficients. ${ }^{a, b}$

\begin{tabular}{lcccc}
\hline & Protein/DNA & $L D H^{\mathrm{c}}$ & ICDH & MHC $\mathrm{I}^{\mathrm{e}}$ \\
\hline Protein DNA & +0.02 & & & \\
LDH $^{\mathrm{c}}$ & -0.11 & +0.05 & & \\
& +0.37 & & & \\
ICDH $^{\mathrm{d}}$ & -0.09 & -0.20 & +0.17 & \\
& -0.22 & -0.30 & & \\
MHC I & +0.10 & -0.44 & +0.31 & -0.07 \\
& -0.38 & -0.48 & +0.41 & \\
Average daily gain & +0.20 & -0.22 & -0.13 & +0.05 \\
& +0.01 & +0.09 & -0.07 & -0.09 \\
Final weight & +0.19 & -0.15 & -0.06 & +0.08 \\
& +0.06 & +0.09 & -0.03 & -0.04 \\
Lean content & -0.05 & -0.05 & -0.08 & -0.09 \\
& +0.10 & +0.08 & -0.06 & -0.14 \\
Fat content & +0.06 & +0.04 & +0.09 & +0.12 \\
& -0.10 & -0.08 & +0.08 & +0.12 \\
\hline
\end{tabular}

${ }^{a}$ First line: ST; second line: $\mathrm{LT} ;{ }^{\mathrm{b}}$ diagonal: correlation between similar characteristics in both muscles; ${ }^{\mathrm{c}} \mathrm{LDH}=$ lactate dehydrogenase activity $;{ }^{\mathrm{d}} \mathrm{ICDH}=$ isocitrate dehydrogenase activity; ${ }^{\mathrm{e}}$ MHC I $=$ proportion of type I myosin heavy chains; $P<0.05$ for $|r| \geqslant 0.17$; $P<0.01$ for $|r| \geqslant 0.21$.

\section{Genetic correlations}

The genetic correlation coefficients are reported in table IV. In general they were much higher than the phenotypic coefficients.

There was a clear genetic antagonism between the glycolytic activity (LDH) and the proportion of type I myosin $\left(r_{g}=-0.72\right.$ and $r_{g}=-0.87$ respectively in the ST and the LT muscle). The oxidative activity (ICDH) was clearly associated with the proportion of type I myosin $\left(r_{g}=+0.64\right.$ and $r_{g}=+0.28$ respectively in both muscles) and opposed, to a lesser extent, to the glycolytic activity $\left(r_{g}=-0.26\right.$ and $r_{g}=-0.33$ respectively in both muscles). These coefficients were homogeneous across muscles and coherent with the observed phenotypic coefficients.

The genetic correlations of these 3 muscle characteristics with carcass composition traits were also highly significant and homogeneous across the muscles. The oxidative activity (ICDH) and the proportion of type I myosin (MHC I) were genetically associated with carcass fat content (respectively $r_{g}=+0.79$ and $r_{g}=+0.68$ 
Table IV. Genetic correlation coefficients. ${ }^{a, b}$

\begin{tabular}{|c|c|c|c|c|}
\hline & Protein/DNA & $L D H^{\mathrm{c}}$ & $I C D H^{\mathrm{d}}$ & $M H C I^{\mathrm{e}}$ \\
\hline Protein DNA & +0.06 & & & \\
\hline $\mathrm{LDH}^{c}$ & $\begin{array}{l}-0.76 \\
+0.79\end{array}$ & +0.02 & & \\
\hline $\mathrm{ICDH}^{\mathrm{d}}$ & $\begin{array}{l}-0.27 \\
-0.66\end{array}$ & $\begin{array}{l}-0.26 \\
-0.33\end{array}$ & +0.64 & \\
\hline MHC I & $\begin{array}{l}+0.29 \\
-0.78\end{array}$ & $\begin{array}{l}-0.72 \\
-0.87\end{array}$ & $\begin{array}{l}+0.64 \\
+0.28\end{array}$ & -0.48 \\
\hline Average daily gain & $\begin{array}{l}+0.76 \\
+0.33\end{array}$ & $\begin{array}{l}-0.63 \\
+0.21\end{array}$ & $\begin{array}{l}-0.28 \\
-0.26\end{array}$ & $\begin{array}{l}+0.31 \\
-0.17\end{array}$ \\
\hline Final weight & $\begin{array}{l}+0.50 \\
-0.01\end{array}$ & $\begin{array}{l}-0.44 \\
-0.22\end{array}$ & $\begin{array}{l}+0.06 \\
-0.18\end{array}$ & $\begin{array}{l}+0.22 \\
-0.00\end{array}$ \\
\hline Lean content & $\begin{array}{l}-0.31 \\
+0.66\end{array}$ & $\begin{array}{l}+0.66 \\
+0.42\end{array}$ & $\begin{array}{l}-0.79 \\
-0.92\end{array}$ & $\begin{array}{l}-0.65 \\
-0.17\end{array}$ \\
\hline Fat content & $\begin{array}{l}+0.26 \\
-0.66\end{array}$ & $\begin{array}{l}-0.69 \\
-0.38\end{array}$ & $\begin{array}{l}+0.79 \\
+0.93\end{array}$ & $\begin{array}{l}+0.68 \\
+0.17\end{array}$ \\
\hline
\end{tabular}

${ }^{a}$ First line: ST; second line: LT; ${ }^{b}$ diagonal: correlation between similar characteristics in both muscles; ${ }^{\mathrm{c}} \mathrm{LDH}=$ lactate dehydrogenase activity; ${ }^{\mathrm{d}} \mathrm{ICDH}=$ isocitrate dehydrogenase activity; ${ }^{\mathrm{e}} \mathrm{MHC} \mathrm{I}=$ proportion of type I myosin heavy chains; approximate se of genetic correlations: $0.40-0.80$ for $\left|r_{g}\right|=0.30 ; 0.30-0.65$ for $\left|r_{g}\right|=0.50 ; 0.20-0.50$ for $\left|r_{g}\right|=0.70$.

in the ST muscle and $r_{g}=+0.93$ and $r_{g}=+0.17$ in the LT muscle) and genetically opposed to carcass lean content (respectively $r_{g}=-0.79$ and $r_{g}=-0.65$ in the ST muscle and $r_{g}=-0.92$ and $r_{g}=-0.17$ in the LT muscle). In contrast, the glycolytic activity $(\mathrm{LDH})$ was genetically associated with carcass lean content $\left(r_{g}=+0.66\right.$ and $r_{g}=+0.42$ respectively in the ST and the LT muscles) and genetically opposed to carcass fat content $\left(r_{g}=-0.69\right.$ and $r_{g}=-0.38$ respectively in both muscles).

The genetic correlations of these 3 characteristics with growth traits were not so clear. In both muscles, a positive correlation appeared between the protein/DNA ratio and daily gain during the fattening period $\left(r_{p}=+0.76\right.$ and $r_{g}=+0.33$ respectively in the ST and the LT muscles). However, the genetic relationship between this protein/DNA ratio and other production traits or muscle characteristics were not similar across muscles.

A principal components analysis has been performed in each muscle to summarize these genetic relationship among muscle characteristics and production traits. The correlations between each trait and the first 2 principal components are shown in figure 1 . In both analyses the first component was primarily explained by the genetic antagonism between lean and fat contents. In both muscles, this first component also clearly discriminated the glycolytic and oxidative activities and the proportion of type I myosin. This clear antagonism between the LDH glycolytic activity on the one hand, the ICDH oxidative activity and the proportion of type I myosin on the other, showed that the division between slow twitch-red fibers (type I) 
Semitendinosus

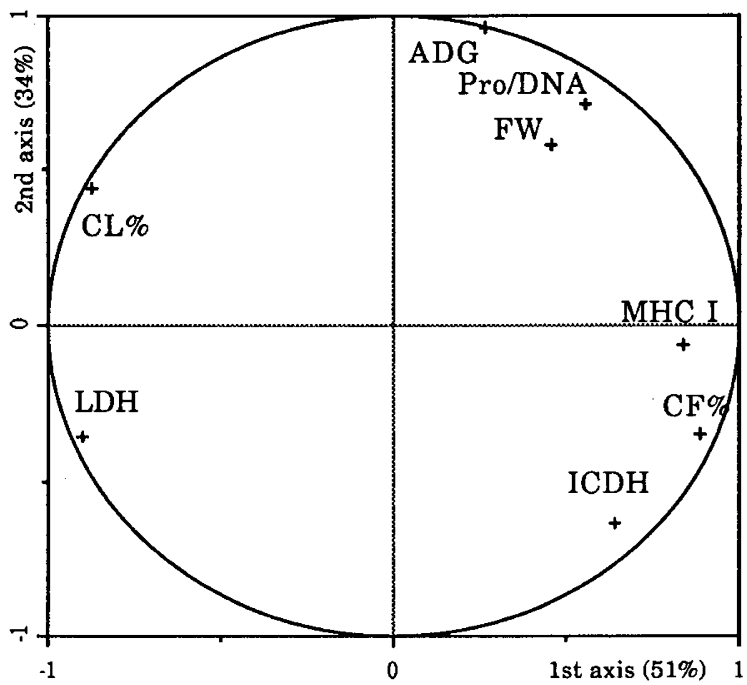

Longissimus dorsi

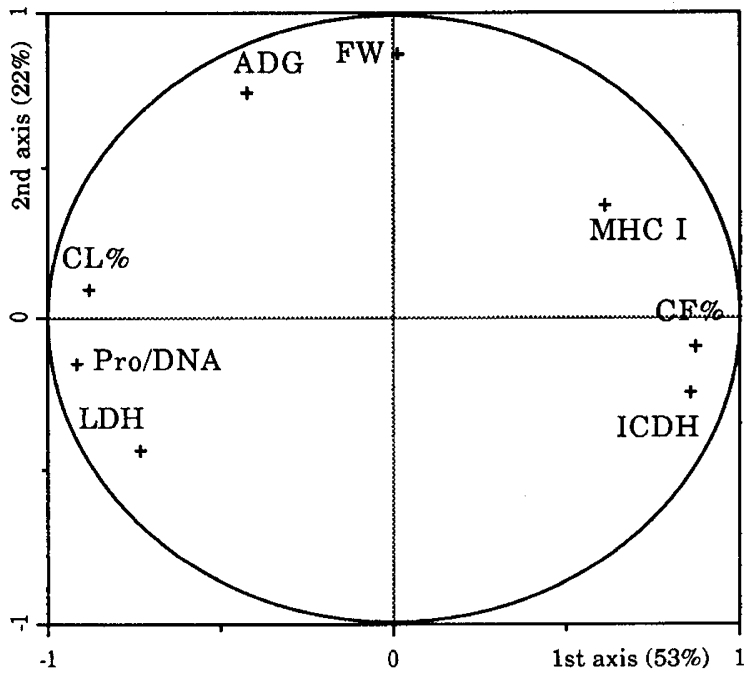

Fig 1. Correlations with the first 2 axes of a principal component analysis on the genetic relationships between growth and carcass traits and biological characteristics of the ST and the Longissimus dorsi. $\mathrm{ADG}=$ average daily gain; $\mathrm{FW}=$ final live weight; CL\% $=$ carcass lean content; $\mathrm{CF} \%=$ carcass fat content; Pro $/ \mathrm{DNA}=$ protein-to-DNA ratio; $\mathrm{LDH}=$ lactate dehydrogenase activity; $\mathrm{ICDH}=$ isocitrate dehydrogenase activity; MHC $\mathrm{I}=$ proportion of type I myosin heavy chains. 
and fast twitch-white fibers (type IIb) was largely under genetic control and was related to the composition of growth. Muscles of the animals that were genetically leaner, also had a higher proportion of glycolytic and fast twitch fibers. The second component was essentially related to the growth capacity. The relative position of the protein/DNA ratio to other traits was different in the 2 muscles and difficult to interpret.

The oxidative activity $(\mathrm{ICDH})$ was the only muscle characteristic that displayed a positive genetic correlation between muscles $\left(r_{g}=+0.64\right)$, while the protein/DNA ratio and the glycolytic activity $(\mathrm{LDH})$ were genetically independent when measured in the ST or in the LT muscle. More surprisingly, the proportion of type I myosin in the ST muscle appeared to be genetically opposed to the same characteristic measured in the LT muscle $\left(r_{g}=-0.48\right)$. The relationship across different muscles need to be studied further since the present results, if confirmed, indicate that the genetic control of the muscle fiber proportions can be quite different in skeletal muscles with different functions. If confirmed, these results would indicate that interactions may exist between genetics and muscle functions.

\section{CONCLUSIONS}

Although measured on animals that were homogeneous as far as breed, sex, age and fattening system were concerned, muscle characteristics of the ST or LT muscles of young bulls were highly variable among individuals, with a significant part that was under genetic control. Although this apparent genetic variability was slightly lower than the corresponding one for production traits, genetic changes of muscle characteristics can be expected if they could be effectively selected in breeding programs. Such selection is theoretically possible since live measurements of these characteristics can be developed using biopsy techniques (Jurie et al, 1995). The choice of the muscles to be sampled depends on the actual genetic relationship that exists between muscle characteristics of different muscles. The most favorable situation would be the lack of interaction between genetics and the muscle function influencing the proportion of different fiber types. Therefore measurements on a single muscle would be sufficient to characterize the genetic ability of the potential young sires.

The present results show that selection for growth capacity is not clearly related to biological characteristics of the ST or LT muscles. In contrast, these characteristics are clearly related to carcass composition traits. The higher the genetic capacity for fattening, the higher the proportion of type I myosin and the more oxidative the enzymatic activity (slow twitch-red fibers). Therefore, even if muscle characteristics are not directly selected, they may change in as much as carcass composition is selected. Selection for leaner animals will increase the proportion of the fast twitch and glycolytic (type IIb) fibers. Although the postmortem aging rate is known to be more rapid (favorable for tenderness) in muscles characterized by this type of fiber (Valin, 1988), the consequences on meat quality of such correlated genetic changes have to be quantified in order to know whether measurements of biological muscle characteristics need to be included in selection programs. 


\section{ACKNOWLEDGMENTS}

Financial support from the Ministère de la Recherche et de la Technologie (Paris) and the UPRA France Limousin Sélection (Limoges) is gratefully acknowledged. Authors are indebted to the staff of the testing station of the GIE France Limousin Testage (Pépieu) and to the technicians of the Institut de l'Elevage (Limoges) for providing the experimental muscle samples. Authors are grateful to D Boichard, INRA CR, Jouy-en-Josas for the multitrait REML software he provided.

\section{REFERENCES}

Andersen BB, Lykke T, Kousgaard K, Buchter L, Pedersen JW (1977) Growth, feed utilization, carcass quality and meat quality in Danish dual purpose cattle. Beret fra Satens Husdyrbrugsforsog 453

Ansay M (1974) Individualité musculaire chez le bovin: étude de l'équipement enzymatique de quelques muscles. Ann Biol Anim Biochim Biophys, 14, 471-486

Briand M, Talmant A, Briand Y, Monin G, Durand R (1981) Metabolic types of muscle in the sheep: I. Myosin ATPase, glycolytic and mitochondrial enzyme activities. Eur $J$ Appl Physiol 46, 347-358

Cundiff LV, Gregory KE, Koch RM, Dickerson GE (1986) Genetic diversity among cattle breeds and its use to increase beef production efficiency in a temperate environment. In: 3rd World Congr on Genet Appl to Livest Prod, University of Nebraska, Lincoln, USA, vol IX, 271-282

Dempster AP, Laird NM, Rubin R (1977) Maximum likelihood estimation from incomplete data via the EM algorithm. $J R$ Stat Soc B 39, 1-20

Dickerson GE (1982) Effect of genetic changes in component of growth on biological and economic efficiency of meat production. In: 2nd World Congr on Genet Appl to Livest Prod, Madrid Editorial Garsi, Madrid, Spain, vol V, 252-267

Jurie C, Robelin J, Picard B, Renand G, Geay Y (1994) Inter-animal variation in the biological characteristics of muscle tissue in male Limousin cattle. Meat Sci (in press)

Jurie C, Robelin J, Picard B, Geay Y (1995) Postnatal changes in biological characteristics of Semitendinosus muscle of Limousin male cattle. Meat Sci (in press)

Koch RM, Cundiff LV, Gregory KE (1982) Heritabilities and genetic, environmental and phenotypic correlations of carcass traits in a population of diverse biological types and their implications in selection progams. J Anim Sci 55, 1319-1329

Labarca C, Paigen K (1980) A simple, rapid and sensitive DNA assay procedure. Anal Biochem 102, 344-352

Lowry OH, Rosebrough NJ, Farr AL, Randall RJ (1951) Protein measurement with the Folin phenol reagent. J Biol Chem 193, 265

Ouali A (1991) Sensory quality of meat as affected by muscle biochemistry and modern technologies. Dev Anim Vet Sci 25, 85-105

Patterson HD, Thompson R (1971) Recovery of inter-block information when block sizes are unequal. Biometrika 58, 545-554

Picard B, Léger J, Robelin J (1994) Quantitative determination of type I myosin heavy chain in bovine muscle with anti-myosin monoclonal antibodies. Meat Sci 36, 333-343

Renand G, Plasse D, Andersen BB (1992) Genetic improvement of cattle for growth and carcass traits. In: Beef Cattle Production (R Jarrige, C Béranger, eds), Elsevier, Amsterdam, The Netherlands, vol C5, 87-108

Renand G (1993) Actual basis for genetic selection in beef. In: INRA-OECD-ECCEAMST International Workshop on Proteolysis and Meat Quality, Clermont-Ferrand, France 
Robelin J, Geay Y (1975) Estimation de la composition des carcasses de jeunes bovins à partir de la compositon d'un morceau monocostal prélevé au niveau de la $11^{\mathrm{e}}$ côte. Ann Zootech 24, 391-402

Sellier P, Bouix J, Renand G, Molénat M (1992) Les aptitudes bouchères : croissance, efficacité alimentaire et qualité de la carcasses. Prod Anim (hors série), 147-159

Staun $H$ (1972) The nutritional and genetic influence on number and size of muscle fibres and their response to carcass quality in pigs. World Rev Anim Prod 8, 18-26

Valin C (1988) Différenciation du tissu musculaire. Conséquences technologiques pour la filière viande. Reprod Nutr Develop 28, 845-856

Vigneron P, Prud'hon M, Touraille C, Valin C, Bouix C, Bibé B (1986) Croissance des agneaux. Types de fibres musculaires et qualités de la viande. Muscles indicateurs. In: $11^{e}$ Journées Rech Ovines et Caprines Paris, ITOVIC, Paris, France, 49-73 